\title{
Trend Analyses of Critical Values Obtained for Energy Consumption Ratio Achievable in Ubicomp MANETs Using Location-Aware Transmission Strategies.
}

\author{
M. Kaleem GALAMALI, Assoc. Prof Nawaz MOHAMUDALLY
}

\begin{abstract}
A promising future lies ahead as concerns research related to location-tracking, MANET transmission and location-aware transmission for ubicomp [1-49]. It is presently accepted that more notable developments must be produced before these fields are subject to fruitful merging and bring about commendable results. One substantial factor for success of such integrated development approach is correct protocol designs. Current methodology of research in protocol designs are heuristic in nature [87] and hence are unsuitable for implementation. Enhancements are awaited in middleware services and architecture $[88,89]$.
\end{abstract}

A relatively further objective in this direction of study is accomplishing realism in design and evaluation of wireless routing protocols [90]. Such formats of research will also yield more usable components for predictability in ubicomp. "Realism" is a broad topic to consider since it will cover each feature related to ubicomp. Such a feature was studied in a prior paper [18] to assess the trend of Energy Consumption Ratio (ECR) achievable under different sets of node densities in a ubicomp environment. This study was upgraded by the corresponding study of trends for each ECR parameter of equations [34].To intensify realism in knowledge of these trends, in this paper, the next stage of investigation that is needed is propounded as: "What are the observable critical values in ECR trends and the trends of these critical values?"

Such knowledge will progressively lead to the design of more realistic ubicomp scenarios which are more distinctly suited for scrupulous testing of newly designed middleware features and communication protocols. This paper is a follow-up of previous investigations [1-49].

Key terms: Ubicomp- Ubiquitous Computing, MAUCMobile and Ubiquitous Computing, ECR- Energy Consumption Ratio, CBR- Constant Bit Rate, MANETMobile Adhoc Network, CV- Critical Value.

M. Kaleem GALAMALI,

University of Technology Mauritius (student)

Mauritius

Assoc. Prof Nawaz Mohamudally University of Technology Mauritius, Mauritius

\section{Introduction}

MANET transmission is accepted as a solution to poor resource availability in ubicomp. It does have significant impacts on the distribution of energy consumption in ubicomp environment [2], which is also heavily influenced by node density. A previous study [18] was aimed at finding the trends observable for metric ECR for varying node densities 7 until 56. The model suggested in that paper [18] was split into two:

- A straight line $F(x)$ from left of the graph towards right until a peak value (at around ECR value 0.3 )

$$
F(x)=d^{\star} x+f
$$

- As from the peak value, trend is smoothly exponentially decreasing and asymptotic to $\mathrm{x}$-axis

$$
G(x)=a * \exp (b *(x-c))
$$

Following this study, another study [34] was formulated to model mathematically the trends of the five parameters of the equations obtained, with the hope that such results may serve towards better understanding of the evolution and predictability of ubicomp environments. With some more progress, designers may produce a platform of realistic simulation scenarios over which testing activities of newly developed components, including communication protocols and middleware functions can be judiciously carried out.

The type of investigation for metric ECR required now is identification of observable critical values obtained during experimentations and formulation of corresponding theoretical trend of such critical values over varying node densities. Eight such critical values have been observed.

The key contribution of this paper is the determination of the trend of variation for each of the eight critical values observed for metric ECR introduced in past papers [18, 34], covering node numbers 7 until 56. Such information, if properly assembled, will aid ubicomp designers to better understand the evolution and predictability of ubicomp behaviour and draw more convenient simulation scenarios over which new communication protocols being implemented could be trustworthily tested. The rest of this paper is organised as follows: section 2- ECR Critical Values, section 3Critical Values Trend Analyses- Metric ECR, section 4- Conclusion and References. 
Proc. of the Seventh International Conference On Advances in Computing, Electronics and Electrical Technology - CEET 2017. Copyright $(C$ Institute of Research Engineers and Doctors. All rights reserved. ISBN: 978-1-63248-126-9 doi: 10.15224/ 978-1-63248-126-9-23

\section{ECR Critical Values.}

\subsection{Critical Values Identified.}

Eight critical values have been identified as follows: Column headings are: $\mathrm{C} 1 \rightarrow \mathrm{ECR} \mathrm{CV}, \mathrm{C} 2 \rightarrow$ Meaning of $\mathrm{ECR} \mathrm{CV}, \mathrm{C} 3 \rightarrow$ Corresponding figure number for the ECR CV.

\begin{tabular}{|l|l|c|}
\hline C1 & C2 & C3 \\
1 & Effective total number of communicating nodes. & 1 \\
\hline 2 & $\begin{array}{l}\% \text { communicating nodes at smallest value of } \\
\text { energy ratio. }\end{array}$ & 2 \\
\hline 3 & $\begin{array}{l}\text { least value of } 1^{\text {st }} \text { five records of energy ratio } \\
4\end{array}$ & $\begin{array}{l}\% \text { communicating nodes at smallest of } 1^{\text {st }} \text { five } \\
\text { records of ECR. }\end{array}$ \\
\hline 5 & $\begin{array}{l}\text { Modal value of energy ratio after first record } \\
6\end{array}$ & $\begin{array}{l}\text { \% communicating nodes at modal value of ECR } \\
\text { after } 1^{\text {st }} \text { record. }\end{array}$ \\
\hline 7 & $\begin{array}{l}\text { \% communicating nodes with energy ratio less } \\
\text { than modal value. }\end{array}$ \\
\hline 8 & $\begin{array}{l}\% \text { communicating nodes with energy ratio } \\
\text { greater than modal value. }\end{array}$ \\
\hline
\end{tabular}

\subsection{Experimental Critical Values Obtained.}

The values obtained during experiments have been summarised below. Values have been rounded to a maximum of 9 decimal places. Column heading $\mathrm{NN} \rightarrow$ Node Number.

\begin{tabular}{|l|l|l|l|l|l|}
\hline NN & CV1 & CV2 & CV3 & CV4 & CV5 \\
\hline 7 & 39726 & 26.496501032 & 0.1 & 3.947037205 & 0.3 \\
\hline 8 & 39598 & 22.367291277 & 0.1 & 3.515329057 & 0.3 \\
\hline 9 & 45729 & 19.580572503 & 0.1 & 3.426709528 & 0.3 \\
\hline 10 & 52462 & 13.838587930 & 0.1 & 3.976211353 & 0.3 \\
\hline 11 & 58297 & 12.576976517 & 0.1 & 3.624543287 & 0.3 \\
\hline 12 & 64293 & 11.309162739 & 0.1 & 3.843342199 & 0.4 \\
\hline 13 & 70845 & 10.281600678 & 0.1 & 3.945232550 & 0.3 \\
\hline 14 & 76746 & 9.494957392 & 0.1 & 3.541552654 & 0.3 \\
\hline 15 & 82882 & 8.911464492 & 0.1 & 3.608744963 & 0.3 \\
\hline 16 & 89052 & 8.324349818 & 0.1 & 3.448546916 & 0.3 \\
\hline 17 & 95628 & 7.626427406 & 0.1 & 3.778182122 & 0.4 \\
\hline 18 & 101666 & 7.225621152 & 0.1 & 3.792811756 & 0.3 \\
\hline 19 & 107775 & 6.898631408 & 0.1 & 3.603804222 & 0.3 \\
\hline 20 & 113850 & 6.531400966 & 0.1 & 3.737373737 & 0.3 \\
\hline 21 & 120413 & 6.069112139 & 0.1 & 3.772848447 & 0.3 \\
\hline 22 & 126393 & 5.755065550 & 0.1 & 3.816667062 & 0.4 \\
\hline 23 & 132559 & 5.520560656 & 0.1 & 3.714572379 & 0.4 \\
\hline 24 & 138628 & 5.293302940 & 0.1 & 3.780621519 & 0.4 \\
\hline 25 & 144722 & 5.057973218 & 0.1 & 3.655283924 & 0.4 \\
\hline 26 & 151847 & 4.868057979 & 0.1 & 3.556869744 & 0.4 \\
\hline 27 & 157821 & 4.700261689 & 0.1 & 3.332256164 & 0.4 \\
\hline 28 & 164089 & 4.560939490 & 0.1 & 3.172059066 & 0.3 \\
\hline 29 & 170191 & 4.424440775 & 0.1 & 3.008972272 & 0.4 \\
\hline 30 & 176428 & 4.227786973 & 0.1 & 3.017094792 & 0.4 \\
\hline 31 & 182026 & 4.156549064 & 0.1 & 3.140210739 & 0.4 \\
\hline 32 & 188211 & 4.070431590 & 0.1 & 3.080053769 & 0.4 \\
\hline 33 & 194318 & 4.020728908 & 0.1 & 3.147932770 & 0.4 \\
\hline 34 & 200385 & 3.958380118 & 0.1 & 3.130473838 & 0.5 \\
\hline 35 & 206622 & 3.776945340 & 0.1 & 3.074212814 & 0.5 \\
\hline 36 & 212735 & 3.660892660 & 0.1 & 3.081298329 & 0.5 \\
\hline 37 & 219868 & 3.522568086 & 0.1 & 3.008623356 & 0.5 \\
\hline 38 & 226002 & 3.420323714 & 0.1 & 2.860594154 & 0.6 \\
\hline 39 & 232193 & 3.420430418 & 0.1 & 2.905341677 & 0.6 \\
\hline & & & & \\
\hline
\end{tabular}

\begin{tabular}{|c|c|c|c|c|c|c|c|}
\hline 40 & 238523 & 3.356489731 & 0.1 & 2.963655497 & 0.5 \\
\hline 41 & 244729 & 3.227243196 & 0.1 & 2.900759616 & 0.5 \\
\hline 42 & 250725 & 3.189151461 & 0.1 & 2.887625885 & 0.5 \\
\hline 43 & 257048 & 2.998272696 & 0.1 & 2.765242289 & 0.5 \\
\hline 44 & 263097 & 2.947582070 & 0.1 & 2.691022703 & 0.6 \\
\hline 45 & 269502 & 2.871963844 & 0.1 & 2.642280948 & 0.5 \\
\hline 46 & 275426 & 2.823989021 & 0.1 & 2.620304546 & 0.3 \\
\hline 47 & 281453 & 2.713063993 & 0.1 & 2.572720845 & 0.5 \\
\hline 48 & 287436 & 2.657635091 & 0.1 & 2.445761839 & 0.5 \\
\hline 49 & 293877 & 2.515678328 & 0.1 & 2.485053271 & 0.4 \\
\hline 50 & 299163 & 2.533401524 & 0.0 & 2.533401524 & 0.6 \\
\hline 51 & 305322 & 2.441356994 & 0.0 & 2.441356994 & 0.6 \\
\hline 52 & 311348 & 2.359738942 & 0.0 & 2.359738942 & 0.4 \\
\hline 53 & 318046 & 2.343371714 & 0.0 & 2.343371714 & 0.4 \\
\hline 54 & 324300 & 2.292013568 & 0.0 & 2.292013568 & 0.4 \\
\hline 55 & 330262 & 2.300597707 & 0.0 & 2.300597707 & 0.4 \\
\hline 56 & 336488 & 2.274078125 & 0.0 & 2.274078125 & 0.5 \\
\hline
\end{tabular}

Table 2a: Experimental Critical Values Obtained(1)

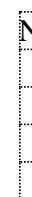

\begin{tabular}{|c|c|c|c|c|}
\hline NN & CV6 & CV7 & CV8 \\
\hline 7 & 5.135175955 & 35.012334491 & 59.852489553 \\
\hline 8 & 4.416889742 & 29.887873125 & 65.695237133 \\
\hline 9 & 4.233637298 & 26.930394279 & 68.835968423 \\
\hline 10 & 4.395562502 & 22.052152034 & 73.552285464 \\
\hline 11 & 4.489081771 & 20.426437038 & 75.084481191 \\
\hline 12 & 4.460827773 & 23.560885322 & 71.978286905 \\
\hline 13 & 4.401157456 & 18.527771896 & 77.071070647 \\
\hline 14 & 4.411956323 & 17.404164386 & 78.183879290 \\
\hline 15 & 4.350763736 & 16.784102700 & 78.865133563 \\
\hline 16 & 4.396307775 & 16.016484750 & 79.587207474 \\
\hline 17 & 4.407704856 & 19.900029280 & 75.692265864 \\
\hline 18 & 4.419373242 & 15.199771802 & 80.380854956 \\
\hline 19 & 4.456506611 & 14.806773370 & 80.736720019 \\
\hline 20 & 4.506807202 & 14.560386473 & 80.932806324 \\
\hline 21 & 4.437228538 & 14.136347404 & 81.426424057 \\
\hline 22 & 4.447239958 & 18.069829817 & 77.482930226 \\
\hline 23 & 4.597198229 & 17.585377077 & 77.817424694 \\
\hline 24 & 4.560406267 & 17.476988776 & 77.962604957 \\
\hline 25 & 4.472022222 & 17.260679095 & 78.267298683 \\
\hline 26 & 4.539437723 & 16.829440160 & 78.631122116 \\
\hline 27 & 4.657174901 & 16.452816799 & 78.890008301 \\
\hline 28 & 4.633461110 & 11.705842561 & 83.660696329 \\
\hline 29 & 4.671222333 & 16.006134284 & 79.322643383 \\
\hline 30 & 4.626816605 & 15.758269662 & 79.614913733 \\
\hline 31 & 4.722402294 & 15.840594201 & 79.437003505 \\
\hline 32 & 4.674540808 & 15.673366594 & 79.652092598 \\
\hline 33 & 4.633641762 & 15.528669501 & 79.837688737 \\
\hline 34 & 4.676996781 & 19.844299723 & 75.478703496 \\
\hline 35 & 4.868310248 & 19.650376049 & 75.481313703 \\
\hline 36 & 4.835593579 & 19.516299622 & 75.648106800 \\
\hline 37 & 4.681445231 & 19.176960722 & 76.141594047 \\
\hline 38 & 4.626065256 & 23.521473261 & 71.852461483 \\
\hline 39 & 4.615987562 & 23.465823690 & 71.918188748 \\
\hline 40 & 4.597460203 & 18.884971261 & 76.517568536 \\
\hline 41 & 4.746474672 & 18.562981911 & 76.690543417 \\
\hline 42 & 4.715923821 & 18.344002393 & 76.940073786 \\
\hline 43 & 4.588637142 & 18.196212381 & 77.215150478 \\
\hline 44 & 4.601724839 & 22.512609418 & 72.885665743 \\
\hline 45 & 4.549502416 & 18.016934939 & 77.433562645 \\
\hline 46 & 4.486867616 & 9.108798734 & 86.404333650 \\
\hline 47 & 4.593306875 & 17.876164049 & 77.530529076 \\
\hline 48 & 4.651818144 & 17.648450438 & 77.699731418 \\
\hline 49 & 4.610091977 & 17.707408201 & 77.682499821 \\
\hline 50 & 4.739222431 & 13.346904530 & 81.913873039 \\
\hline 51 & 4.677684543 & 22.288600232 & 73.033715225 \\
\hline 52 & 4.639181880 & 13.051633542 & 82.309184578 \\
\hline 53 & 4.683913648 & 13.127346359 & 82.188739994 \\
\hline & & & \\
\hline
\end{tabular}


Proc. of the Seventh International Conference On Advances in Computing, Electronics and Electrical Technology - CEET 2017. Copyright $(C$ Institute of Research Engineers and Doctors. All rights reserved.

ISBN: 978-1-63248-126-9 doi: 10.15224/ 978-1-63248-126-9-23

\begin{tabular}{|l|l|l|l|l|}
\hline 54 & 4.648165279 & 13.135676842 & 82.216157879 \\
\hline 55 & 4.605131683 & 13.267042530 & 82.127825787 \\
\hline 56 & 4.625424978 & 17.790233233 & 77.584341789 \\
\hline
\end{tabular}

Table 2b: Experimental Critical Values Obtained(2)

\section{Critical Values Trend Analyses- Metric ECR.}

\subsection{General Procedure Adopted.}

The tabulated data for each ECR CV is plotted on gnuplot over Linux. Graphical analyses using the "Fit" command is performed supported by the smooth bezier plot. For each such graph obtained, the major observations are reported. Again, various equations of fit are exerted and their summary report is produced for each ECR CV. In the end, for one CV, choice is made based on flat values, and for the remaining seven critical values, choice is based on values of least reduced chi-square and most plausible extendability produced at node numbers 80,100 and 120 . Finally, the values of parameters for each equation corresponding to ECR CV is also recorded.

\subsection{Trend Analysis - ECR CVI.}

The tendency here is clearly linear increasing.

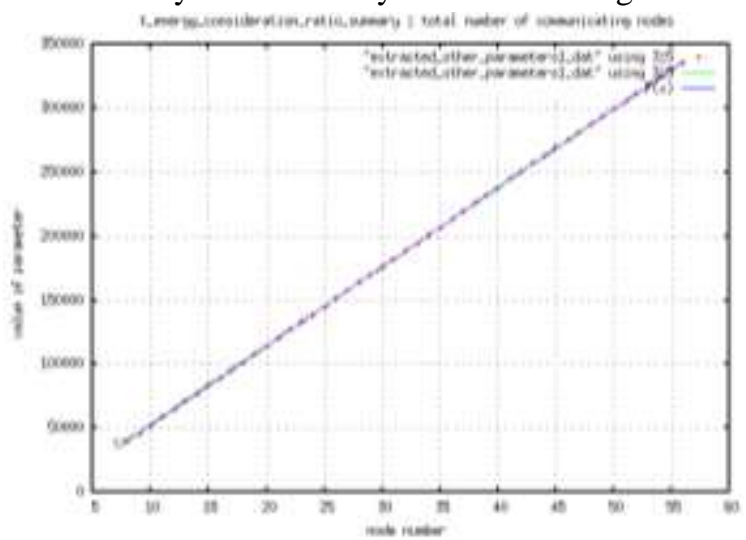

Figure 1: ECR Critical Value 1

$F(x)=d^{\star} x+f$

Ch_sq $=870696$

$\mathrm{F}(80)=484951.386746697$

$\mathrm{F}(100)=608471.587466984 \quad \mathrm{~F}(120)=731991.788187272$

Parameters for best fit are: $\mathrm{d}=6176.01, \mathrm{f}=-9129.42$

It should be noted that ch_sq is not 0 and that the $y$ intervals are very large 0-50 000. Hence, it is understandable that if the figure is expanded significantly, the distances of the plots from the line of best fit will be visible.

\subsection{Trend Analysis - ECR CV2.}

Generally, the curve decreases at a decreasing rate.

The potentially applicable equations are:

1. $F(x)=a \star \exp ((b \star x)+c)+d$

$$
\begin{array}{ll}
\text { Ch_sq }=0.682329 & F(80)=3.227912143 \\
F(100)=3.227819754 & F(120)=3.227816609
\end{array}
$$

2. $F(x)=a * \exp ((b * x)+c)+\left(d^{*} x^{-1}\right)$

$$
\text { Ch_sq }=0.135493 \quad \mathrm{~F}(80)=1.593923521
$$$$
\mathrm{F}(100)=1.275138817 \quad \mathrm{~F}(120)=1.062615681
$$

3. $F(x)=a * \exp ((b * x)+c)+\left(d^{*} x^{-1.5}\right)$

$$
\begin{array}{ll}
\text { Ch_sq }=0.237172 & F(80)=2.194165859 \\
F(100)=2.142040428 & F(120)=2.173598709
\end{array}
$$

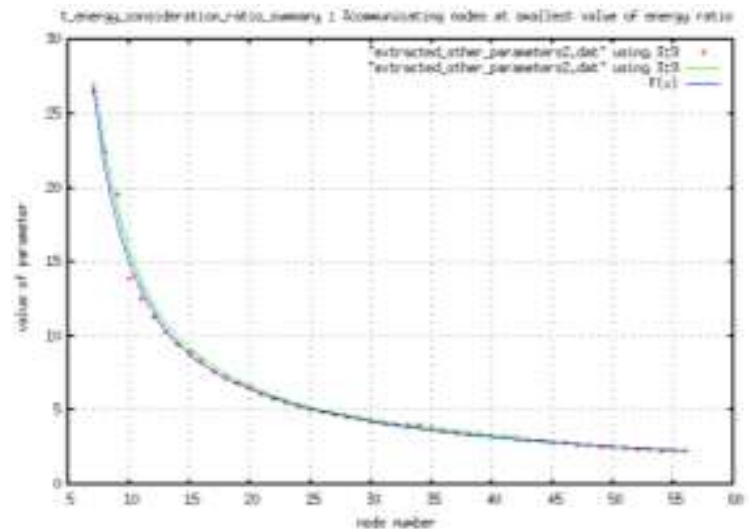

Figure 2: ECR Critical Value 2

Choice of best fit for ECR Critical Value 2

The equation in part 2 above has been selected because of smallest ch_sq and good extendability. The parameters obtained for best fit are:

$\mathrm{a}=3.99781, \mathrm{~b}=-0.427801, \mathrm{c}=3.79135, \mathrm{~d}=127.514$

\subsection{Trend Analysis - ECR CV3.}

Two sets of observation are made here:

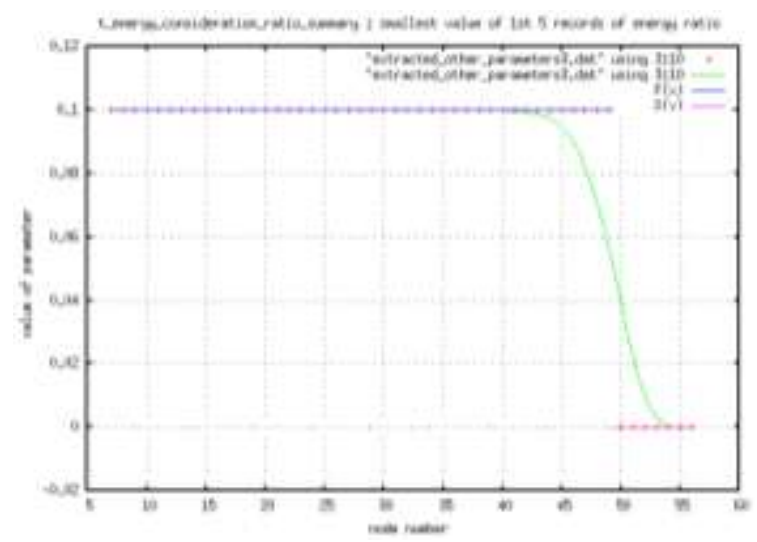

Figure 3: ECR Critical Value 3

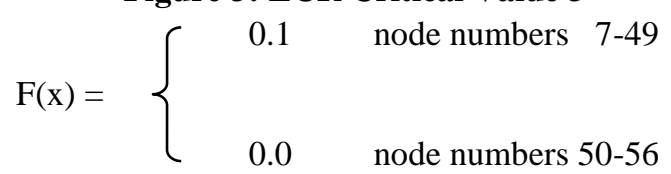

Projected values for $\mathrm{F}(\mathrm{x})$ for node numbers larger than 56 are 0.0 .

\subsection{Trend Analysis - ECR CV4.}

For node number 7 till 24, value is quite stable between 3.5 and 3.9. After node number 24, trend is decreasing. 
Proc. of the Seventh International Conference On Advances in Computing, Electronics and Electrical Technology - CEET 2017. Copyright (C) Institute of Research Engineers and Doctors. All rights reserved.

ISBN: 978-1-63248-126-9 doi: 10.15224/ 978-1-63248-126-9-23

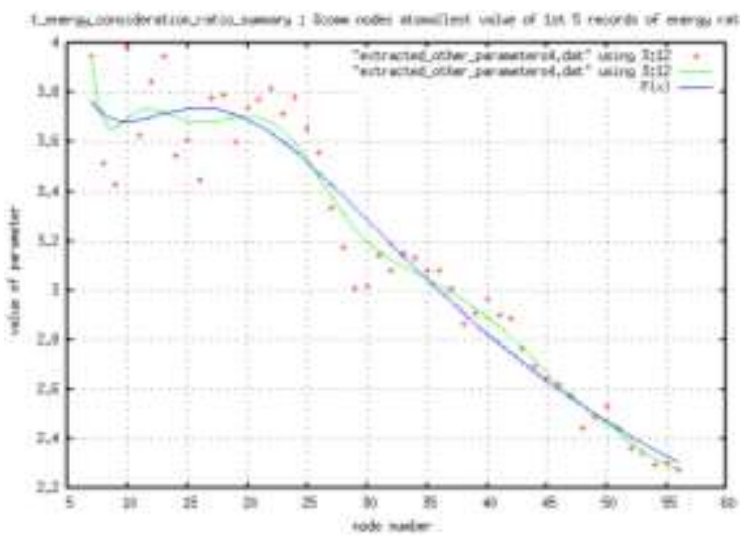

Figure 4: ECR Critical Value 4

The potentially applicable equations are:

1. $F(x)=\left(a *(x+h)^{f}+g\right) /(\exp (($ $\mathrm{b} *(\mathrm{x}+\mathrm{h}))+\mathrm{c})+\mathrm{d}$

Ch_sq $=0.0218194 \quad \mathrm{~F}(80)=1.884168148$

$\mathrm{F}(100)=1.682300417 \quad \mathrm{~F}(120)=1.546365345$

2. $F(x)=\left(a *(x+h)^{f}+g\right) /(\exp$

$((b *(x+h))+c)+\left(d * x^{-0.5}\right)$

Ch_sq $=0.0210711 \quad \mathrm{~F}(80)=1.376199047$

$\mathrm{F}(100)=0.904254571 \quad \mathrm{~F}(120)=0.582724244$

3. $F(x)=\left(a *(x+h)^{f}+g\right) /(\exp$

$((b *(x+h))+c)+\left(d * x^{-0.25}\right)$

Ch_sq $=0.0217107 \quad \mathrm{~F}(80)=1.850437223$

$\mathrm{F}(100)=1.621705093 \quad \mathrm{~F}(120)=1.461227192$

\section{Choice of best fit for ECR Critical Value 4}

The equation in part 3 above has been selected because of better extendability even if ch_sq is not smallest. The parameters obtained for best fit are:

$\mathrm{a}=2.93865, \mathrm{~b}=-0.162908, \mathrm{c}=-1.49021, \mathrm{~d}=0.080$

$0988, \mathrm{f}=-0.956381, \mathrm{~g}=0.00526742, \mathrm{~h}=0.3344$.

\subsection{Trend Analysis - ECR CV5.}

Plottings depict a staircase feature because values are rounded to nearest 1 d.p. trend appears oscillating.

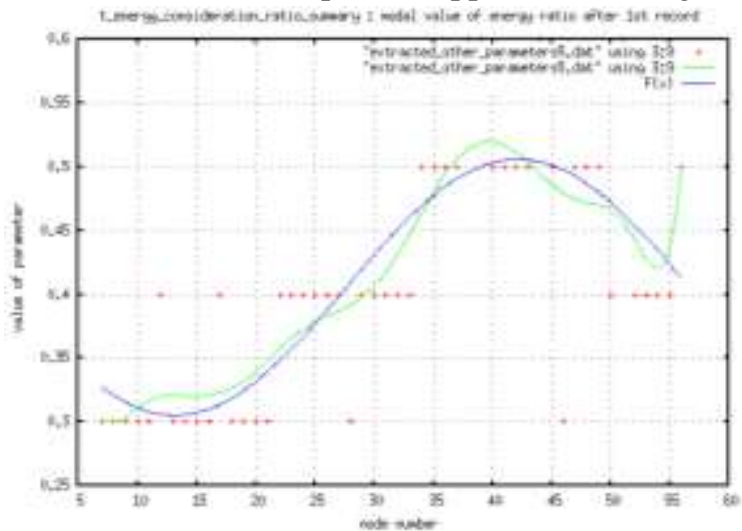

Figure 5: ECR Critical Value 5

$F(x)=a * \sin ((b * x)+c)+d$

Ch_sq $=0.00345064 \quad \mathrm{~F}(80)=0.348174193$

$\mathrm{F}(100)=0.506140615 \quad \mathrm{~F}(120)=0.350366335$
The parameters of fit are: $\mathrm{a}=-0.100442, \mathrm{~b}=0.108$ $376, c=0.144795, d=0.405707$.

\subsection{Trend Analysis - ECR CV6.}

The trend obtained appears to be a damping oscillation along an axis with a positive gradient.

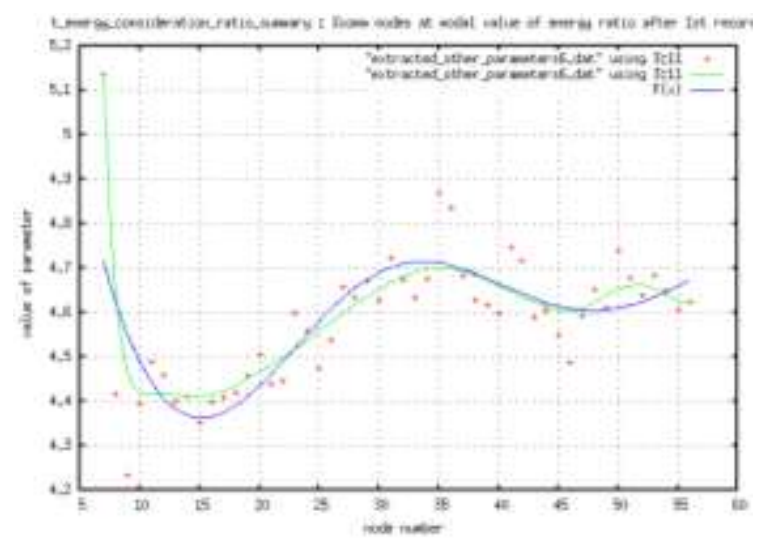

Figure 6: ECR Critical Value 6

$$
\begin{array}{ll}
F(x)=f * x^{-1} \star \sin & ((a * x)+b)+c * x+d \\
\text { Ch_sq }=0.0111612 & F(80)=4.737649052 \\
F(100)=4.871689596 & F(120)=4.894547771
\end{array}
$$

The parameters of fit are: $a=0.193604, b=4.50913$ $, c=0.0033447, d=4.50659, f=-3.20696$

\subsection{Trend Analysis - ECR CV7.}

Mostly, three ranges for trends are observed here. Each range shows decreasing trend at decreasing rate. The ranges and applicable equations are:

$$
\mathrm{F}(\mathrm{x})=\left\{\begin{array}{lr}
\mathrm{a} * \exp \left(\left(\mathrm{b}^{*} \mathrm{x}\right)+\mathrm{c}\right)+\mathrm{d} & 7 \leq \mathrm{x} \leq 21 \\
\mathrm{f} * \exp ((\mathrm{g} * \mathrm{x})+\mathrm{h})+\mathrm{i} & 22 \leq \mathrm{x} \leq 33 \\
\mathrm{j} * \exp \left(\left(\mathrm{k}^{*} \mathrm{x}\right)+1\right)+\mathrm{m} & 34 \leq \mathrm{x} \leq 56
\end{array}\right.
$$

For node number 7 until 21:

$$
\text { ch_sq }=3.13761, \mathrm{a}=2.75572, \mathrm{~b}=-0.25089
$$
, $c=3.74282, d=14.4509$

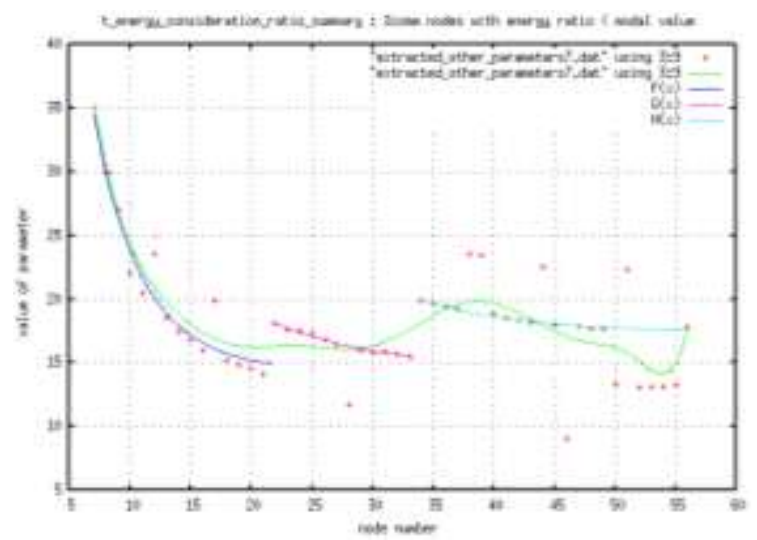

Figure 7: ECR Critical Value 7

For node number 22 until 33: 
Proc. of the Seventh International Conference On Advances in Computing, Electronics and Electrical Technology - CEET 2017. Copyright $(C$ Institute of Research Engineers and Doctors. All rights reserved.

ISBN: 978-1-63248-126-9 doi: 10.15224/ 978-1-63248-126-9-23

ch_sq $=0.0180713, \mathrm{f}=2.57187, \mathrm{~g}=-0.103$ $559, \mathrm{~h}=2.67895, \mathrm{i}=14.2529$

For node number 34 until 56:

$$
\text { ch_sq }=0.0229584, \mathrm{j}=3.0548, \mathrm{k}=-0.117
$$

$119, \mathrm{l}=3.81938, \mathrm{~m}=17.3574$

Suggestion: Last equation for $\mathrm{F}(\mathrm{x})$ may be used for predictability over larger node numbers.

\subsection{Trend Analysis - ECR CV8.}

Here also, three ranges of trends are observed here. Each range shows an increasing trend at a decreasing rate. The ranges and applicable equations are:

$$
\mathrm{F}(\mathrm{x})=\left\{\begin{array}{lc}
\mathrm{a} * \log ((\mathrm{b} * \mathrm{x})+\mathrm{c})+\mathrm{d} & 7 \leq \mathrm{x} \leq 21 \\
\mathrm{f} * \log ((\mathrm{g} * \mathrm{x})+\mathrm{h})+\mathrm{i} & 22 \leq \mathrm{x} \leq 33 \\
\mathrm{j} * \log \left(\left(\mathrm{k}^{*} \mathrm{x}\right)+1\right)+\mathrm{m} & 34 \leq \mathrm{x} \leq 56
\end{array}\right.
$$

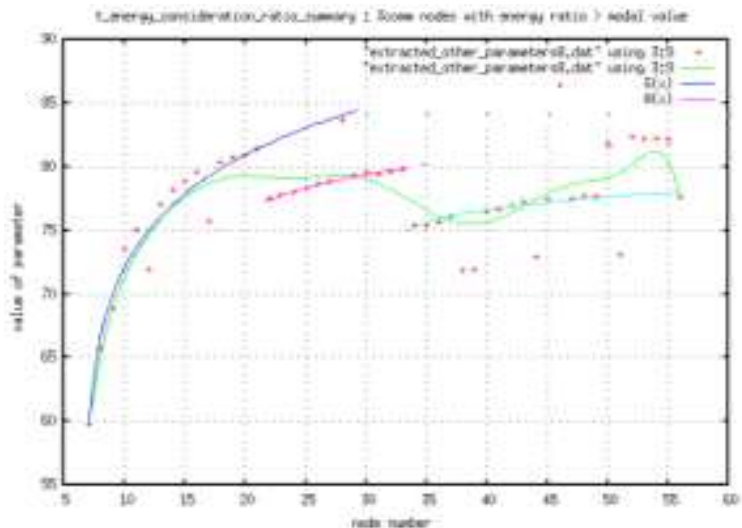

Figure 8: ECR Critical Value 8

For node number 7 until 21:

$$
\text { ch_sq }=2.94988, \mathrm{a}=6.74201, \mathrm{~b}=4.3548 \text {, }
$$

$\mathrm{c}=-27.971, \mathrm{~d}=53.4464$

For node number 22 until 33:

$$
\text { ch_sq }=0.0156356, \mathrm{f}=2.44568, \mathrm{~g}=4.294
$$

$09, \mathrm{~h}=-66.785, \mathrm{i}=69.31$

For node number 34 until 56:

$$
\text { ch_sq }=0.0531288, \mathrm{j}=1.34644, \mathrm{k}=5.371
$$

$95,1=-164.916, \mathrm{~m}=71.3916$

It is suggested that the last equation for $\mathrm{F}(\mathrm{x})$ may be used for predictability over larger node numbers.

\section{Conclusion.}

This piece of research was aimed at identifying some critical values pertaining to metric ECR and study their corresponding trends over varying node densities in a MANET topography. The report of this investigation is successfully produced here. The models detailed here are of mathematical nature of varying levels of complexity which will assist in studying MANETs for MAUC environment from the angle of software engineering. Such mathematical models may pretty easily be implemented as programming algorithms to engender more rigorously realistic simulation scenarios using which, novel communication protocols and middleware components developed for ubicomp may be tested.

This experiments were executed in NS-2 over Linux. The plottings and "Fit" attempts were done in gnuplot. Best fit was selected based on least reduced chi-square values and best extendability of equations at higher node numbers except for one critical value where flat values have been used. Assumptions stated in past papers $[18,34]$ are upheld here also.

This work is a follow-up of previous papers [1-13, 18, 34] and stays succeptible for future extensions. One such further work identified is the formulation of a method of predictability for metric ECR and its trend.

\section{References}

[1] M. Kaleem GALAMALI, Assoc. Prof Nawaz MOHAMUDALLY, Towards Dependable Pervasive Systems-A Position and Vision Paper, CEET 2014

[2] M. Kaleem GALAMALI, Assoc. Prof Nawaz MOHAMUDALLY, Model of Energy Savings achievable with Location-aware Node-to-Node Transmission in UbiComp , CEET 2014

[3] M. Kaleem GALAMALI, Assoc. Prof Nawaz MOHAMUDALLY, Model of Energy Savings achievable with Location-aware Node-to-Node Transmission in UbiComp Using Location Refresh Intervals, CEET 2014

[4] M. Kaleem GALAMALI, Assoc. Prof Nawaz MOHAMUDALLY, Model of Energy Savings achievable with Location-aware Transmission in UbiComp Using Relays, CEET 2014

[5] M. Kaleem GALAMALI, Assoc. Prof Nawaz MOHAMUDALLY, Mathematical modeling of need of exact number of relays to ensure seamless mobility in mobile computing, CEET 2014

[6] M. Kaleem GALAMALI, Assoc. Prof Nawaz MOHAMUDALLY, Modelling of need for multiple relays for ensuring seamless mobility, CEET 2014

[7] M. Kaleem GALAMALI, Assoc. Prof Nawaz MOHAMUDALLY, Investigation of prominence of placements of relays in a ubicomp topography,

[8] M. Kaleem GALAMALI, Assoc. Prof Nawaz MOHAMUDALLY, Model of energy savings achievable with location-aware transmission in ubicomp using optimised number of relays.

[9] M. Kaleem GALAMALI, Assoc. Prof Nawaz MOHAMUDALLY, Investigation of Prominence of Placements of Optimised Number of Relays in a Ubicomp Topography using Location-Aware Transmission, CEET 2015.

[10] M. Kaleem GALAMALI, Assoc. Prof Nawaz MOHAMUDALLY, Extending Node Battery Availability in Ubicomp with Location-Aware Transmission, CEET 2015.

[11] M. Kaleem GALAMALI, Assoc. Prof Nawaz MOHAMUDALLY, Extending Node Battery Availability in Ubicomp with Location-Aware Transmission using Location Refresh Intervals, CEET 2015.

[12] M. Kaleem GALAMALI, Assoc. Prof Nawaz MOHAMUDALLY, Extending Node Battery Availability in Ubicomp with Location-Aware Transmission using 
Uniformly Placed Relays, CEET 2015.

[13] M. Kaleem GALAMALI, Assoc. Prof Nawaz MOHAMUDALLY, Extending Node Battery Availability in Ubicomp with Location-Aware Transmission Using Optimally Placed Relays, CEET 2015

[14] M. Kaleem GALAMALI, Assoc. Prof Nawaz MOHAMUDALLY, Model of Sender Node Energy Savings Achievable with Location-Aware MANET Transmission in Ubicomp. ACCN 2016

[15] M. Kaleem GALAMALI, Assoc. Prof Nawaz MOHAMUDALLY, Model of Overall Node Energy Savings Achievable with Location-Aware MANET Transmission in Ubicomp. ACCN 2016

[16] M. Kaleem GALAMALI, Assoc. Prof Nawaz MOHAMUDALLY, Model of Sender Node Extra Energy Savings Achievable in MANET Against Direct Node-toNode Transmission Using Location-Aware Transmission in Ubicomp. ACCN 2016

[17] M. Kaleem GALAMALI, Assoc. Prof Nawaz MOHAMUDALLY, Model of Overall Node Extra Energy Savings Achievable in MANET against Direct Node-toNode Transmission Using Location-Aware Transmission in Ubicomp. ACCN 2016

[18] M. Kaleem GALAMALI, Assoc. Prof Nawaz MOHAMUDALLY, Model of Energy Consumption Ratio Achievable in MANET Using Location-Aware Transmission in Ubicomp. ACCN 2016

[19] M. Kaleem GALAMALI, Assoc. Prof Nawaz MOHAMUDALLY, Model of Minimum Energy Consumption Ratio Achievable in MANET Using LocationAware Transmission in Ubicomp. ACCN 2016

[20] M. Kaleem GALAMALI, Assoc. Prof Nawaz MOHAMUDALLY, Model of Maximum Energy Consumption Ratio Achievable in MANET Using LocationAware Transmission in Ubicomp. ACCN 2016

[21] M. Kaleem GALAMALI, Assoc. Prof Nawaz

MOHAMUDALLY, Model of Overall Energy Consumption Fairness Ratio Achievable in MANET Using LocationAware Transmission in Ubicomp. ACCN 2016

[22] M. Kaleem GALAMALI, Assoc. Prof Nawaz MOHAMUDALLY, Model of Overall Energy Consumption Fairness Proportion Achievable in MANET Using LocationAware Transmission for Ubicomp, CEET 2016

[23] M. Kaleem GALAMALI, Assoc. Prof Nawaz MOHAMUDALLY, Model of Minimum Fairness Proportion Achievable in MANET Using Location-Aware Transmission for Ubicomp, CEET 2016

[24] M. Kaleem GALAMALI, Assoc. Prof Nawaz MOHAMUDALLY, Model of Maximum Fairness Proportion Achievable in MANET Using Location-Aware Transmission for Ubicomp, CEET 2016

[25] M. Kaleem GALAMALI, Assoc. Prof Nawaz MOHAMUDALLY, Model of Sender Fairness Proportion Achievable in MANET Using Location-Aware Transmission for Ubicomp, CEET 2016

[26] M. Kaleem GALAMALI, Assoc. Prof Nawaz MOHAMUDALLY, Model of Distance Travelled by packets in MANETs using Location-Aware Transmission for Ubicomp, CEET 2016

[27] M. Kaleem GALAMALI, Assoc. Prof Nawaz MOHAMUDALLY, Model of Maximum CBR Distance Travelled by packets in MANETs using Location-Aware Transmission for Ubicomp, CEET 2016

[28] M. Kaleem GALAMALI, Assoc. Prof Nawaz MOHAMUDALLY, Model of Minimum CBR Distance Travelled by packets in MANETs using Location-Aware Transmission for Ubicomp, CEET 2016

[29] M. Kaleem GALAMALI, Assoc. Prof Nawaz MOHAMUDALLY, Model of Range CBR Distance Experienced by Transmissions in MANETs using LocationAware Transmission for Ubicomp, CEET 2016

[30] M. Kaleem GALAMALI, Assoc. Prof Nawaz MOHAMUDALLY, Trend Analyses of Parameters of Equations for Sender Node Energy Savings Achievable in ubicomp MANETs using Location-Aware Transmission, ACCN 2017.

[31] M. Kaleem GALAMALI, Assoc. Prof Nawaz MOHAMUDALLY, Trend Analyses of Parameters of Equations for Overall Node Energy Savings Achievable in ubicomp MANETs using Location-Aware Transmission, ACCN 2017.

[32] M. Kaleem GALAMALI, Assoc. Prof Nawaz MOHAMUDALLY, Trend Analyses of Parameters of Equations for Sender Node Extra Energy Savings Achievable in MANET against Direct Node-to-Node Location-Aware Transmission, ACCN 2017.

[33] M. Kaleem GALAMALI, Assoc. Prof Nawaz MOHAMUDALLY, Trend Analyses of Parameters of Equations for Overall Nodes Extra Energy Savings Achievable in MANET against Direct Node-to-Node Location-Aware Transmission, ACCN 2017.

[34] M. Kaleem GALAMALI, Assoc. Prof Nawaz MOHAMUDALLY, Trend Analyses of Parameters of Equations for Energy Consumption Ratio Achievable in Ubicomp MANET Using Location-Aware Transmission, ACCN 2017.

[35] M. Kaleem GALAMALI, Assoc. Prof Nawaz MOHAMUDALLY, Trend Analyses of Parameters of Equations for Minimum Energy Consumption Ratio Achievable in Ubicomp MANETs Using Location-Aware Transmission, ACCN 2017.

[36] M. Kaleem GALAMALI, Assoc. Prof Nawaz MOHAMUDALLY, Trend Analyses of Parameters of Equations for Maximum Energy Consumption Ratio Achievable in Ubicomp MANETs Using Location-Aware Transmission, ACCN 2017.

[37] M. Kaleem GALAMALI, Assoc. Prof Nawaz MOHAMUDALLY, Trend Analyses of Parameters of Equations for Overall Fairness Ratio Achievable in Ubicomp MANETs Using Location-Aware Transmission, ACCN 2017.

[38] M. Kaleem GALAMALI, Assoc. Prof Nawaz MOHAMUDALLY, Trend Analyses of Parameters of Equations for Energy Consumption Fairness Proportion Achievable in Ubicomp MANETs Using Location-Aware Transmission, CEET 2017

[39] M. Kaleem GALAMALI, Assoc. Prof Nawaz MOHAMUDALLY, Trend Analyses of Parameters of Equations for Minimum Fairness Proportion Achievable in Ubicomp MANETs Using Location-Aware Transmission, CEET 2017

[40] M. Kaleem GALAMALI, Assoc. Prof Nawaz MOHAMUDALLY, Trend Analyses of Parameters of Equations for Maximum Fairness Proportion Achievable in Ubicomp MANETs Using Location-Aware Transmission, CEET 2017

[41] M. Kaleem GALAMALI, Assoc. Prof Nawaz MOHAMUDALLY, Trend Analyses of Parameters of Equations for Sender Fairness Proportion Achievable in Ubicomp MANETs Using Location-Aware Transmission, CEET 2017

[42] M. Kaleem GALAMALI, Assoc. Prof Nawaz MOHAMUDALLY, Trend Analyses of Parameters of Equations for Packets Per Distance Achievable in Ubicomp MANETs Using Location-Aware Transmission, CEET 2017

[43] M. Kaleem GALAMALI, Assoc. Prof Nawaz MOHAMUDALLY, Trend Analyses of Parameters of Equations for Maximum CBR Distance Achievable in Ubicomp MANETs Using Location-Aware Transmission, CEET 2017

[44] M. Kaleem GALAMALI, Assoc. Prof Nawaz MOHAMUDALLY, Trend Analyses of Parameters of Equations for Minimum CBR Distance Achievable in Ubicomp MANETs Using Location-Aware Transmission, CEET 2017

[45] M. Kaleem GALAMALI, Assoc. Prof Nawaz MOHAMUDALLY, Trend Analyses of Parameters of Equations for Range CBR Distance Achievable in Ubicomp MANETs Using Location-Aware Transmission, CEET 2017

[46] M. Kaleem GALAMALI, Assoc. Prof Nawaz MOHAMUDALLY, Trend Analyses of Critical Values Obtained for Sender Node Energy Savings Achievable in Ubicomp MANETs Using Location-Aware Transmission, CEET 2017

[47] M. Kaleem GALAMALI, Assoc. Prof Nawaz MOHAMUDALLY, Trend Analyses of Critical Values Obtained for Overall Node Energy Savings Achievable in Ubicomp MANETs Using Location-Aware Transmission, CEET 2017 
[48] M. Kaleem GALAMALI, Assoc. Prof Nawaz MOHAMUDALLY, Trend Analyses of Critical Values Obtained for Sender Node Extra Energy Savings Achievable in Ubicomp MANET Against Direct Node-to-Node Location-Aware Transmission, CEET 2017

[49] M. Kaleem GALAMALI, Assoc. Prof Nawaz MOHAMUDALLY, Trend Analyses of Critical Values Obtained for Overall Nodes Extra Energy Savings Achievable in Ubicomp MANET Against Direct Node-toNode Location-Aware Transmission, CEET 2017

[50] Markus Bylund and Zary Segall, Towards seamless mobility with personal servers, 2004

[51] Masugi Inoue, Mikio Hasegawa, Nobuo Ryoki and Hiroyuki Morikawa, Context-Based Seamless Network and Application Control, 2004

[52] Xiang Song, Umakishore Ramachandran, MobiGo: A Middleware for Seamless Mobility, College of Computing Georgia Institute of Technology, Atlanta, GA, USA, August 2007

[53] Budzisz, Ferrús, R., Brunstrom A., Grinnemo, K, Fracchia, R., Galante, G., and Casadevall, F. Towards transport-layer mobility: Evolution of SCTP multihoming, March 2008

[54] Paul Dourish \& Genevieve Bell, Divining a digital future, 2011.

[55] Xiang Song, Seamless Mobility In Ubiquitous Computing Environments, PhD Thesis, Georgia Institute of Technology, August 2008

[56] Kevin O Mahony, Jian Liang, Kieran Delaney, User-Centric Personalization and Autonomous Reconfiguration Across Ubiquitous Computing Environments, NIMBUS Centre Cork Institute of Technology, Cork, Ireland, UBICOMM 2012

[57] Pablo Vidales, Seamless mobility in 4G systems, Technical Report, University of Cambridge, Computer Laboratory, Number 656, November 2005

[58] João Pedro Sousa and David Garlan, Aura: An Architectural Framework for User Mobility in Ubiquitous Computing Environments, School of Computer Science, Carnegie Mellon University, USA, August 2002

[59] Dennis Lupiana, Ciaran O'Driscoll, Fredrick Mtenzi, Defining Smart Space in the Context of Ubiquitous Computing, Dublin Institute of Technology, Ireland, Special Issue on ICIT 2009 Conference - Web and Agent Systems, 2009

[60] N.S.V.Shet1, Prof.K.Chandrasekaran2 and Prof. K.C.Shet3, WAP Based Seamless Roaming In Urban Environment with Wise Handoff Technique, International Journal of UbiComp (IJU), Vol.1, No.4, October 2010

[61] Yipeng Yu Dan He Weidong Hua Shijian Li Yu Q Yueming Wang Gang Pan, FlyingBuddy2: A Braincontrolled Assistant for the Handicapped, Zhejiang University, UbiComp'12, September 5-8, 2012.

[62] Jing Su, James Scott, Pan Hui, Jon Crowcroft, Eyal de Lara Christophe Diot, Ashvin Goel, Meng How Lim, and Eben Upton, Haggle: Seamless Networking for Mobile Applications, 2007

[63] Rui Han, Moustafa M. Ghanem, Li Guo, Yike Guo*, Michelle Osmond, Enabling cost-aware and adaptive elasticity of multi-tier cloud applications, Future Generation Computer Systems, 2012

[64] Byrav Ramamurthy, K. K. Ramakrishnan, Rakesh K. Sinha, Cost and Reliability Considerations in Designing the NextGeneration IP over WDM Backbone Networks, 2012.

[65] Bhavish Aggarwal, Aditya Akella, Ashok Anand, Athula Balachandran, Pushkar Chitnis, Chitra Muthukrishnan, Ram Ramjee and George Varghese, EndRE: An End-System Redundancy Elimination Service for Enterprises, NSDI 2010, San Jose, CA

[66] Ashok Anand, Vyas Sekar and Aditya Akella, SmartRE: An Architecture for Coordinated Network-wide Redundancy Elimination, SIGCOMM 2009, Barcelona, Spain

[67] John Breeden II, "Smart-phone battery life could double without better batteries", Nov 14, 2012

[68] Andy Boxall, "When will your phone battery last as long as your kindle", December 5, 2012.

[69] Imielinski, T. and Navas, J.C. (1999). GPS-based geographic addressing, routing, and resource discovery. Comms. ACM, Vol. 42, No. 4, pp. 86-92.

[70] Hightower, J. and Borriello, G. (2001). Location Systems for Ubiquitous Computing. IEEE Computer, Vol. 34, No. 8, August, pp. 57-66.

[71] Harter, A., Hopper, A., Steggles, P., Ward, A. and Webster,
P. (2002). The Anatomy of a Context-Aware Application. Wireless Networks, Vol. 8, No. 2-3, Mar-May, pp. 187-197.

[72] Hightower, J., Brumitt, B. and Borriello, G. (2002). The Location Stack: A Layered Model for Location in Ubiquitous Computing. Proceedings of the 4th IEEE Workshop on Mobile Computing Systems \& Applications (WMCSA 2002), Callicoon, NY, USA, June, pp. 22-28.

[73] Graumann, D., Lara, W., Hightower, J. and Borriello, G. (2003). Real-world implementation of the Location Stack: The Universal Location Framework. Proceedings of the 5th IEEE Workshop on Mobile Computing Systems \& Applications (WMCSA 2003), Monterey, CA, USA, October, pp. 122-128

[74] Ko, Y., \& Vaidya, N. H. (2000). Location-aided routing (LAR) in mobile ad hoc networks. Wireless Networks, 6(4), 307-321.

[75] Liao, W.-H., Tseng, Y.-C., \& Sheu, J.-P. (2001). GRID: a fully location-aware routing protocol for mobile ad hoc networks. Telecommunication Systems, 18(1), 37-60.

[76] Kuhn, F., Wattenhofer, R., Zhang, Y., \& Zollinger, A. (2003). Geometric ad-hoc routing: of theory and practice. In Proceedings of the ACM (PODC'03) (pp. 63-72).

[77] Jiang, X., \& Camp, T. (2002). Review of geocasting protocols for a mobile ad hoc network. In Proceedings of the Grace Hopper Celebration (GHC).

[78] Ko, Y. \& Vaidya, N. H. (1999). Geocasting in mobile ad hoc networks: location-based multicast algorithms. In Proceedings of the IEEE (WMCSA'99) (pp. 101).

[79] Mauve, M., Fuler, H., Widmer, J., \& Lang, T. (2003). Position-based multicast routing for mobile ad-hoc networks (Technical Report TR-03-004). Department of Computer Science, University of Mannheim.

[80] Xu, Y., Heidemann, J., \& Estrin, D. (2001). Geographyinformed energy conservation for adhoc routing. In Proceedings of the ACM/IEEE (MOBICOM'01) (pp. 70-84).

[81] Hu, Y.-C., Perrig, A., \& Johnson, D. (2003). Packet leashes: a defense against wormhole attacks in wireless ad hoc networks. In Proceedings of the INFOCOM' 03 (pp. 1976-1986).

[82] Patwari, N., Hero III, A. O., Perkins, M., Correal, N. S., \& O’Dea, R. J. (2003). Relative location estimation in wireless sensor networks. IEEE Transactions on Signal Processing, 51(8), 2137-2148.

[83] Baldauf, M., Dustdar, S., \& Rosenberg, F. (2007). A Survey on Context Aware Systems. International Journal of Ad Hoc and Ubiquitous Computing, Inderscience Publishers. forthcoming. Pre-print from: http://www.vitalab.tuwien.ac.at/ florian/papers/ijahuc2007.pdf

[84] Hong, D., Chiu, D.K.W., \& Shen, V.Y. (2005). Requirements elicitation for the design of context-aware applications in a ubiquitous environment. In Proceedings of ICEC'05 (pp. 590-596).

[85] Neeraj Tantubay, Dinesh Ratan Gautam and Mukesh Kumar Dhariwal, A Review of Power Conservation in Wireless Mobile Ad hoc Network (MANET)", International Journal of computer Science Issues, Vol 8, Issue 4, No 1, July 2011.

[86] Wenrui Zhao, Mostafa Ammar and Ellen Zegura, "A Message Ferrying Approach for Data Delivery in Sparse Mobile Ad Hoc Networks", MobiHoc'04, May 24-26, 2004, Roppongi, Japan.

[87] Sgroi et al., "Designing Wireless Protocols: Methodology and Applications, February 2000.

[88] Gyula et al., "Simulation-based optimization of communication protocols for large-scale wireless sensor networks", 10 October 2002

[89] Rao and Sharma, "Cross Layer Protocols For Multimedia Transmission in Wireless Networks", June 2012

[90] Herms et al, "Realism in Design and Evaluation of Wireless Routing Protocols", 2007.

About Author (s): 
Proc. of the Seventh International Conference On Advances in Computing, Electronics and Electrical Technology - CEET 2017. Copyright (C) Institute of Research Engineers and Doctors. All rights reserved.

ISBN: 978-1-63248-126-9 doi: 10.15224/ 978-1-63248-126-9-23

Associate Professor Nawaz Mohamudally works at University of Technology, Mauritius (UTM) and has undertaken supervision of MPhil/PhD Students for many years.

M. Kaleem Galamali is a part-time student (achieved M Phil Transfer on 28.10.2014, currently PhD student) at UTM under supervision of A.P. Nawaz Mohamudally. 